\title{
Exploring the Effectiveness of Cooperative Learning at Secondary Level in Bangladesh
}

Md. Solaiman JONY ${ }^{1}$

\begin{tabular}{l} 
ARTICLE INFO \\
\hline Article History: \\
Received 28.04.2019 \\
Received in revised form \\
30.11 .2019 \\
Accepted \\
Available online 01.01 .2020
\end{tabular}

\section{INTRODUCTION}

\begin{abstract}
In general, cooperative learning refers to the use of small groups of students to encourage them to work together and help each other to learn, accomplish learning goals, and increase their learning potential. This study attempts to explore the effectiveness of cooperative learning at secondary level classroom learning and students' achievement in particular. It also compares the achievements in means of scores between a student group taught using cooperative learning strategies and another group taught using non-cooperative learning strategies. This study is designed following a quasiexperimental research technique. 60 students from a secondary school of class 9 taking Science from 2 different sections were selected as samples and were divided into equal number experimental group and control group for this study. A pretest was conducted before administering the cooperative learning technique which was followed by a post-test after on to determine the effectiveness in the form of learning achievement. Students' achievements were measured through a self-constructed achievement test which was used in both the pretest and post-test. The data were analyzed through t-test using SPSS. The comparison of these results indicated a meaningful statistical difference between the two groups, and it was also found from the teachers that students who work in the cooperative learning groups were more engaged, more responsible in completing group assignments and more organized while working in their respective groups. Therefore, in order to promote quality learning, the results of this study may encourage the practice of cooperative learning for the secondary school level. To make the learning of students more enjoyable, effective, and sustained at secondary level; schools and teachers need to use the cooperative learning technique in the classrooms.
\end{abstract}

C IJERE. All rights reserved

Keywords:

Effectiveness of cooperative leaning, cooperative learning, students' academic achievement, quasiexperimental design.

Cooperation works together to accomplish shared goals. Individuals seek outcomes that are beneficial to themselves and beneficial to all other group members within cooperative activities. Cooperative learning $(\mathrm{CL})$ is the instructional use of small groups so that students work together to maximize their own and each other's learning (Johnson, Johnson \& Holubec, 1993). Therefore, cooperative learning refers to an instruction method in which students of various performance levels work together in small groups toward a common goal. Class members are organized into small groups after receiving instruction from the teacher. They, then, work through the assignment or task until all group members successfully understand and complete it. Cooperative efforts result in participants striving for mutual benefit so that all group members gain from each other's efforts (Johnson and Johnson, 1989).

There are many studies reported which indicate the cooperative learning environment is more effective than the individual learning environment. For example, Karagöz (2018) states that Sadrettin Celal Antel has that CL be a part of the curricula of newly founded Turkish Republic. This suggestion made it possible so that CL was applied to curricula in Turkey. According to Sloffer, Dueber, and Duffy (1999), Johnson and Johnson (1996), there is persuasive evidence that cooperative team activities achieve at higher levels of thought and retain information longer than students who work individually. The shared learning gives students an opportunity to engage in discussion, take responsibility for their own learning, and thus become critical thinkers (Totten, Sills, Digby, \& Russ, 1991). Students who cooperate are introduced to an environment that prepares them well to succeed in the workforce by putting emphasis on teamwork activities (McLoughlin \& Luca, 2002; Romano \& Nunamaker, 1998).

In contrast to cooperative situations, competitive situations are ones in which students work against each other to achieve a goal that only one or a few can attain. In competition there is a negative interdependence among goal achievements; students perceive that they can obtain their goals if and only if

1 Corresponding e-mail: jonysolaiman@gmail.com, https://orcid.org/0000-0003-0433-0878 1 Corresponding e-mail: jonysolaiman@gmail.com, https://orcid.org/0000-0
Institute of Education and Research, Education School, Khulna University 
the other students in the class fail to obtain their goals (Deutsch, 1962; Johnson \& Johnson, 1989). The result is that students either work hard to do better than their classmates, or they take it easy because they do not believe they have a chance to win. In individualistic learning situations students work alone to accomplish goals unrelated to those of classmates and are evaluated on a criterion-referenced basis. Students' goal achievements are independent; students perceive that the achievement of their learning goals is unrelated to what other students do. The result is to focus on self-interest and personal success and ignore as irrelevant the successes and failures of others.

Collaborative learning has been described as "the use of small groups through which students work together to accomplish shared goals and to maximize their own and others' potential" (Johnson, Johnson, \& Holubec, 1998 cited in Parveen, Mahmood, Mahmood, \& Arif, 2011). The teacher's role is to create an environment where young people are willing and able to work collaboratively. The environment must also provide plenty of opportunities and stimulating contexts for learners to work with others, and in which they feel safe to share their emerging ideas and understanding.

There is a long history of research on cooperative, competitive, and individualistic efforts. Since the first research study in 1898, nearly 600 experimental studies and over 100 co-relational studies have been conducted (Johnson \& Johnson, 1989). The multiple outcomes studied can be classified into three major categories: achievement/productivity, positive relationships, and psychological health. The research clearly indicates that cooperation, compared with competitive and individualistic efforts, typically results in (a) higher achievement and greater productivity, (b) more caring, supportive, and committed relationships, and (c) greater psychological health, social competence, and self-esteem. The positive effects that cooperation has on so many important outcomes makes cooperative learning one of the most valuable tools educators have.

Even though collaborative learning has been found to be relatively effective, not many teachers allow students to work in collaborative groups. Teachers have expressed particular concern about loss of classroom control, increased disruption and off-task behavior (Cohen \& Intilli 1981; Cohen 1994). Teachers also worry that children have difficulty learning from one another (Lewis \& Cowie 1993). The nature of group work is time consuming, that the assessment of children in interactive groups is difficult, and that positive outcomes are limited to the more academically able students (Plummer \& Dudley 1993). Teachers have also expressed the view that pupils, particularly boys, will misbehave during group work and that discussion within group work may cause conflict between pupils (Cowie 1994). Galton (1990), found that some children often feel insecure and threatened when told to work in groups and pupils responded to this threat by withdrawal from participation or depending on the teacher to give legitimacy to their responses within groups.

Placing students in groups and telling them to work together does not result in cooperation. The essential components of cooperation are positive interdependence, face-to-face interaction, individual and group accountability, interpersonal and small group skills, and group processing (Johnson, Johnson, \& Holubec, 1998).

For effective collaboration, group members must actively communicate and interact with each other with the intention of establishing a common focus and achieving a common goal (Akkerman et al. 2007; Beers et al. 2006).

\section{Statement of the problem and purpose of the study}

This study 'Exploring the Effectiveness of Cooperative Learning at Secondary Level in Bangladesh' has been undertaken to determine the effectiveness of cooperative learning approach in secondary academic institutions by exploring whether the students' learn better and more effectively in an environment of cooperative learning rather than working as individuals or pair work.

This research was conducted in a selected secondary school in Dhaka, Bangladesh to explore the effectiveness of cooperative learning on students' academic performance and attitudes of teachers towards cooperative learning effects. Samad (2005) [cited in Hossain, Tarmizi, 2013] mentioned from the findings of his study which has been conducted in the secondary school mathematics classrooms in Bangladesh that teachers are familiar with conventional mode of thought and teaching; teachers' teaching strategies are based on their individual creativity. He commented that this traditional teaching strategy has negative impact on 
students' performance in secondary school certificate (SSC) examination. He stresses the need of involvement of secondary teachers with those methods of teaching which have positive impact on students' academic performance.

Effandi (2003) found cooperative learning improved students' achievement in mathematics and attitudes towards mathematics. He concluded that utilization of cooperative learning method is a preferable alternative to traditional instructional method.

However, despite the accepted accomplishment of CL, the practices of this technique in classrooms are not very much familiar, because in classroom setting, it is not always easy to introduce the technique due to resistance from both the teachers and students. According to Njenga (2010), there are two major difficulties to the successful implementation of a CL environment at the secondary school level. First, most secondary school teachers lack training in CL. Second, middle and high school students lack the social skills necessary to work effectively in cooperative groups.

Therefore, this study focused to explore the effects of cooperative learning on students' academic performance at secondary level and attitudes of teachers towards cooperative learning.

\section{Objectives of the Study}

The objectives of this study were: (i.) to explore the effectiveness of cooperative learning on students' achievement, (ii.) to make a comparison of cooperative learning effects on students' achievement between experimental and control group, (iii.) to find out the perceptions of teachers about the effectiveness of cooperative learning.

\section{Hypothesis of the Study}

$$
\mathrm{H}_{0}: \mu_{\text {control group }}-\mu_{\text {experimental group }}=0
$$

There are no significant mean scores difference between the achievement scores of control and experimental groups after intervention. Therefore, the alternative hypothesis of this study is H1: the mean scores difference of the achievement scores of the control group is lower than that of the experimental group.

\section{METHODOLOGY}

A quasi-experimental pre-test and post-test control group design was administered to identify the effects of cooperative learning in the experimental schools. The quasi-experimental design compared a control group using conventional teaching method with an experimental group using cooperative learning.

The population of the study consisted of 60 students from 2 different sections of class 9 studying in a secondary school in Dhaka, Bangladesh. The school, selected for this study, was chosen by the researcher based on convenience of the researcher. To select the sample size, the researcher used the purposive sampling technique. Both boys and girls, aged 14-15 years, were participants of this research, however, there were no intention to maintain the ratio of gender and ethnicity as the purpose of the study did not required so. Students from the different sections were dived into experimental group and control group. In order to measure academic achievement of the sample in the subject before and after the experiment, an achievement test was designed. The test contained twenty items consisting of true/false type, multiple choice types, matching type and short answer type. The content covered in the test included prior knowledge and new subject matter to be taught during the experiment. The time duration of the test was half an hour which was considered to be appropriate for completing the test by all students well in time. For data analyses, SPSS 25.0 Statistical Package Program was used.

The teaching learning materials used in the study while giving treatment of cooperative learning to the experimental group was not different from the control group except the treatment. The design of the study was the 'pre-test post-test control group design' which in one of the forms of true quasi-experimental design. This design in described in table 1. 
Table1. Pre- and -post- test control group design

\begin{tabular}{cccc}
\hline Group & Pre-test & Treatment & Post-test \\
\hline A $(n=30)$ & $\mathrm{O}_{1}$ & $X$ & $\mathrm{O}_{2}$ \\
$B(n=30)$ & $\mathrm{O}_{1}$ & & $\mathrm{O}_{2}$ \\
\hline
\end{tabular}

A questionnaire containing descriptive questions was used for teachers of the selected school to determine their perceptions about the effectiveness of cooperative learning. Teachers were interviewed on the questionnaire. In analyzing the qualitative data, the evidence and response obtained from the interview, a descriptive approach was used. Different themes emerged from the data related to cooperative learning, its usefulness, and the role of teacher in cooperative learning have been identified and data have been analyzed under each theme. Six teachers were selected randomly for this study.

\section{FINDINGS OF THE STUDY}

\section{Identifying the effectiveness of cooperative learning on students' achievement}

Independent sample t-test was conducted in comparing the achievements of the two groups. The posttest mean scores of students' achievement for the experimental group taught by the cooperative learning technique was 13.30 ( $\mathrm{SD}=2.23$ ), and the achievement for the control group taught by the conventional teaching was $11.70(\mathrm{SD}=2.31)$. Table 2 shows that the mean for the experimental group $(\mathrm{M}=13.30)$ was greater than that for the control group $(\mathrm{M}=11.70)$.

Table 2. Mean difference of the control group and experimental group in pre and post test

\begin{tabular}{|c|c|c|c|c|c|}
\hline & Student Group & $\mathbf{N}$ & Mean & $\begin{array}{r}\text { Std. } \\
\text { Deviation } \\
\end{array}$ & $\begin{array}{l}\text { Std. Error } \\
\text { Mean }\end{array}$ \\
\hline \multirow[t]{2}{*}{ Pre-test } & Control Group & 30 & 11.53 & 3.298 & .602 \\
\hline & Experimental Group & 30 & 11.63 & 2.428 & .443 \\
\hline \multirow[t]{2}{*}{ Post-test } & Control Group & 30 & 11.70 & 2.307 & .421 \\
\hline & Experimental Group & 30 & 13.30 & 2.231 & .407 \\
\hline
\end{tabular}

As a rule of thumb, if Sig. $>0.05$, we conclude that the assumption of equal variances holds. For posttest (in table 3), since Sig. $=0.801$, therefore, we report the first line of $t$ test results, denoted as equal variances assumed. If the Sig (2-Tailed) value $(p)$ is less than or equal to 0.05 , we reject the null hypothesis and conclude that there is a statistically significant difference between two conditions. In such case, we can conclude that the differences between condition Means are not likely due to change and are probably due to the intervention.

The independent t-test analysis (in table 3) revealed that the performance of experimental group was significantly better than control group. The table shows that there was a substantial difference in achievement score of the experiment group; pre-test $(M=11.63, S D=2.42)$ and post-test $(M=13.30, S D=2.23), t$ $(58)=-2.731, p=0.008<0.05$. Hence, cooperative learning positively affects students' achievement. 
Table 3. Independent Sample t-test for Pre-test and Post-test of Students' Achievement

\begin{tabular}{|c|c|c|c|c|c|c|c|c|c|c|}
\hline \multicolumn{11}{|c|}{ Independent sample t-test } \\
\hline & & \multicolumn{2}{|c|}{$\begin{array}{c}\text { Levene's Test } \\
\text { for Equality of } \\
\text { Variances } \\
\end{array}$} & \multicolumn{7}{|c|}{ t-test for Equality of Means } \\
\hline & & \multirow[b]{2}{*}{$\mathrm{F}$} & \multirow[b]{2}{*}{ Sig. } & \multirow[b]{2}{*}{$\mathrm{T}$} & \multirow[b]{2}{*}{$\mathrm{Df}$} & \multirow{2}{*}{$\begin{array}{l}\text { Sig. (2- } \\
\text { tailed) }\end{array}$} & \multirow{2}{*}{$\begin{array}{c}\text { Mean } \\
\text { Difference }\end{array}$} & \multirow{2}{*}{$\begin{array}{l}\text { Std. Error } \\
\text { Difference }\end{array}$} & \multicolumn{2}{|c|}{$\begin{array}{c}95 \% \text { Confidence } \\
\text { Interval of the } \\
\text { Difference }\end{array}$} \\
\hline & & & & & & & & & Lower & Upper \\
\hline \multirow[t]{2}{*}{$\begin{array}{l}\text { Pre- } \\
\text { test }\end{array}$} & $\begin{array}{l}\text { Equal variances } \\
\text { assumed } \\
\end{array}$ & 3.923 & .052 & -.134 & 58 & .894 & -.100 & .748 & -1.597 & 1.397 \\
\hline & $\begin{array}{l}\text { Equal variances } \\
\text { not assumed }\end{array}$ & & & -.134 & 53.297 & .894 & -.100 & .748 & -1.600 & 1.400 \\
\hline \multirow[t]{2}{*}{$\begin{array}{l}\text { Post- } \\
\text { test }\end{array}$} & $\begin{array}{l}\text { Equal variances } \\
\text { assumed } \\
\end{array}$ & .064 & .801 & -2.731 & 58 & .008 & -1.600 & .586 & -2.773 & -.427 \\
\hline & $\begin{array}{l}\text { Equal variances } \\
\text { not assumed }\end{array}$ & & & -2.731 & 57.935 & .008 & -1.600 & .586 & -2.773 & -.427 \\
\hline
\end{tabular}

\section{Perceptions of teachers about the effectiveness of cooperative learning}

Cooperative Learning attractions: Respondents agreed with the statement that cooperative learning increases the level of learning for all students, especially the weak students, by attracting them toward a different and useful teaching approach. According to the teachers it is an efficient learning strategy in the classroom.

Social and cognitive Benefits: Teachers agreed that cooperative learning promotes the level of confidence in face to face interaction among the students and it helps students to accept others opinions. The impact of the interaction occurred during the learning process boost the formation of social skills among the students. They also confirmed that cooperative learning allows the students to nurture their creativity by practicing individual concepts and ideas while learning in the classroom discussion. It also improves the understanding ability of the students.

Student Participation: The cooperative learning approach brings democratic conversation among the students by providing opportunities for students to speak and get involved into their academic activities. Teachers have very positive views on how cooperative learning can increase student participation in the learning process.

Role of Teachers: Teachers agreed that if cooperative learning is practiced in the classroom, students will not be required to depend only on the teachers. However, the teachers agreed that sometimes it will be difficult to control the learning activities while using cooperative learning approach in the classroom and it may end up into a messy classroom if the teacher is not in the control of the learning process. It also requires a long time to complete the syllabus in a required timeline and takes more time for the teachers to prepare. Apart from controlling the class, time is also one of the constraints in the implementation of cooperative learning.

\section{DISCUSSION AND RECOMMENDATIONS}

The study was carried out to explore the effectiveness of cooperative learning on students' academic achievement in local context. Findings from this study show that cooperative learning has significant effect on students' achievement. The experimental group demonstrates significant improvement in achievement in comparison to the control group. The result indicates that the upsurge of post-test mean scores for the experimental group was due to the significant effects of cooperative learning. The findings of the study, 
therefore, are consistent with the results as reported by Davidson (1990), Johnson and Johnson (1994), Whicker et al. (1997), Faizah (1999), Vaughan (2002), Effandi (2003), Ozsoy and Yildiz (2004), Ainley (2006), Zakaria et al. (2010), Thurston et al. (2010), Shimazoe and Al-drich (2010), Melihan and Sirri (2011), Hossain and Tarmizi (2013) and Gull and Shehzad (2015) (cited in Hossain \& Tarmizi 2013, and Gull, \& Shehzad, 2015).

The study also explores the perceptions of the teachers towards the effectiveness of cooperative learning. The result from the teachers' interview indicates that students who work in the cooperative learning groups are more engaged and attracted to learning. The students are proved to be more responsible in completing group assignments and more organized while working in their respective groups. The learning approach develops the social skills and creativity among the participated students. However, the teachers also mentioned few limitations of the cooperative learning approach which include lack of classroom infrastructure facility, lack of preparation from teachers' perspective, time constrains and huge academic syllabus may confine the teachers to introduce this approach into the classroom.

A noteworthy difference in students' achievement was found between the experimental and the control groups from this particular study. After introducing the treatment, collaborative learning, to the experimental group students showed significant improvement in their achievement in comparison to the control group students. The findings of this study may assist the policymakers and teachers to take appropriate measures to promote cooperative learning in science classrooms.

The study was carried out with a small group of participants and for a limited period of time. Therefore, the results may not be equally effective to every teaching learning context. To find out true effectiveness of the cooperative learning method, further research needs to be conducted on large sample to intensify the generalizability of the findings of this study.

\section{REFERENCES}

Alias, S., Hussin, H., Hassan, J, Adnan, N. \& Othman, M. \& Kamarudin, H. (2018). Perception of teacher on cooperative learning. MATEC Web of Conferences 150, 05068.

Gull, F., \& Shehzad, S. (2015). Effects of cooperative learning on students' academic achievement. Journal of Education and Learning, 9(3), 246-255.

Hossain, A., \& Tarmizi, R. A. (2013). Effects of cooperative learning on students' achievement and attitudes in secondary mathematics. Procedia-Social and Behavioral Sciences, 93, 473-477.

Johnson, D. W., Johnson R. T., \& Holubec, E. J. (1993). Cooperation in the classroom (6th ed.). MN: Interaction Book Company.

Johnson, D. W., \& Johnson, R. T. (1989). Cooperation and competition: Theory and research. Edina, MN: Interaction Book Company.

Karagöz, S. (2018). Sadrettin Celal Antel's ten-year ministry development report: an assessment based on the divisions of educational sciences. Universal Journal of Educational Research, 6(5), 1119-1128, DOI: 10.13189 /ujer. 2018. 060533

Keramati, M. (2010). Effect of cooperative learning on academic achievement of physics course. Journal of computers in mathematics and science teaching, 29(2), 155-173.

Njenga, J. (2010). Evaluation of the effectiveness of cooperative learning structures in improving students' performance. Retrieve from https://pdfs.semanticscholar.org/0f40/c4c00fb4ae88d0e33655892a08f5fadc2235.pdf

Parveen, Q., Mahmood, S. T., Mahmood, A., \& Arif, M. (2011). Effect of cooperative learning on academic achievement of 8 th grade students in the subject of social studies. International Journal of Academic Research, 3(1), 950-954.

Slavin, R. E. (2015). Cooperative learning in elementary schools. Education, 3-13, 43(1), 5-14. 
Sutherland, K. S., Wehby, J. H., \& Gunter, P. L. (2000). The effectiveness of cooperative learning with students with emotional and behavioral disorders: A literature review. Behavioral Disorders, 25(3), 225-238.

Vaughan, W. (2002). Effects of cooperative learning on achievement and attitude among students of color. The Journal of Educational Research, 95(6), 359-364. 